\title{
The influence of UV radiation on number and ultrastructure of the endosymbiotic dinoflagellates in the sea anemone Cereus pedunculatus (Anthozoa: Actiniaria)
}

\author{
K. Hannack, P. Kestler, O. Sicken \& W. Westheide* \\ University of Osnabrück, Department of Biology \& Chemistry, Systemutic Zoology, \\ Barbarastraße 11, 49069 Osnabrück, Germany
}

\begin{abstract}
The sea anemone Cereus pedunculatus was artificially UV-irradiated to test the effect of UV-light on the number of endosymbiotic dinoflagellates in its gastrodermis and on their ultrastructure. Anemones were kept in the laboratory in a light:dark cycle (LD) 12:12:13 W m 4 dt $18{ }^{\circ} \mathrm{C}$ and briefly $(2,5$ and $9 \mathrm{~d})$ exposed to UV radiation at quasisolar intensities, 0.5 or $1 \mathrm{~W} \mathrm{~m}^{2}$. Their tentacles were then examined in the electron microscope for qualitative and quantitative changes in the zooxanthellae. There was an intensity-dependent decrease in the number of symbionts, which in some cases were lost altogether (bleaching). Irradiated anemones contained a larger proportion of symbionts with ultrastructural abnormalities, namely diminished starch, some mitochondria with altered matrix and, in particular, characteristic changes in the chloroplasts: instead of being densely stacked. the thylakoids were spread apart and swollen at the ends of their membranes to form vesicle-like structures. Relatively large vesicles also appeared in the cytoplasm. The resliting eniargernent of the whole dinoflagellate cell was documented morphometrically. Another intensity-dependent effect was a significant decrease in mitosis rate, established by counting dividing symbiont cells in TEM micrographs.
\end{abstract}

\section{INTRODUCTION}

Many Cnidaria, especially Anthozod, contain large populations of unicellular zooxanthellae (dinoflagellates) which make an important contribution to the cnidarian metabolism and, in some cases, to the construction of skeletal formations (McLaughlin et al., 1964; Taylor, 1973; Muscatine, 1973, 1980; Cook, 1983; Douglas et al., 1993).

"Bleaching" is the term applied to the discoloration caused by the more or less complete loss of these autotrophic endosymbionts or at least their pigments; it most commonly occurs in reef-inhabiting species belonging to the Madreporaria, Gorgonaria, Actiniaria, and Zoantharia. This is an often observed, but not generally lethal phenomenon (Gates, 1990; Hayes \& Bush, 1990), the causes of which are not yet entirely understood and remain controversial despite much investigation (Fisk \& Done, 1985; Williams et al., 1987; Brown \& Suharsono, 1990; Grigg \& Dollar, 1990; Brown et al., 1994).

In many field observations and laboratory experiments, mainly involving corals, the influences of diverse environmental factors on bleaching have been examined. Other

\footnotetext{
- Addressee for all correspondence.
} 
than variations in salinity (Pierce \& Minasian, 1974; Benson-Rodenbourgh \& Ellington, 1982; Høegh-Guldberg \& Smith, 1989), the main factor studied has been increasing seawater temperature, which has been found to induce this effect (Jokiel \& Coles, 1974, 1977, 1990; Glynn, 1991, 1993, 1996; Cook et al., 1990; Gates, 1990; Lasker et al., 1984; Jaap, 1985; Suharsono \& Brown, 1992; Brown \& Ogden, 1993). In the laboratory an increase in water temperature raised the respiration rate of corals and reduced the rate of photosynthesis by their symbiotic algae (Coles \& Jokiel, 1977; Høegh-Guldberg \& Smith, 1989). Lesser et al. (1990) observed that fewer zooxanthellae were present, while there were larger amounts of the enzymes that protect the coral from active oxygen radicals released by the zooxanthellae.

It is becoming increasingly clear, however, that an increase in seawater temperatures alone cannot be responsible for the phenomenon. Kushmaro et al. (1996) have recently shown that bacterial infection causes bleaching of the coral species Oculina patagonica. It has been claimed for some time that sunlight, especially its UV component, is responsible for the disruption of cnidarian-algal symbioses (Gleason \& Wellington, 1993; Shick et al., 1996). The influence of intensity and spectral composition of the light on the response of the zooxanthellae in cnidarians was investigated by Steele (1976), Fisk \& Done (1985), Lesser \& Shick (1989), Achituv \& Dubinsky (1990) and Harland et al. (1992). That the impairment of symbiosis is due chiefly to the short-wavelength part of the spectrum $(280-400 \mathrm{~nm})$ has been shown by Lesser et al. (1990), Kinzie (1993), Harland \& Davies (1994), and Brown et al. (1994). Now that the anthropogenic. rise in stratospheric ozone concentration is becoming more pronounced, with a correlated increase in the global increase in UV-B irradiation, these observations have particularly significant implications for the marine aquatic habitat and its organisms (Tevini, 1993; Häder, 1996). Light is especially important in the habitat of the corals, for the clear water in the tropics is relatively transparent to UV-A (31.5-400 nm) and UV-B (280-31.5 nm) (Shick et al., 1996). By contrast, in parts of the ocean with high organic productivity much of the short-wavelength radiation is absorbed in the superficial layers (Smith \& Tyler, 1976; Smith \& Baker, 1979, 1984; Calkins, 1982; Fleischmann, 1989; Gieskes \& Kraay, 1990). Corals and other anthozoans that live in symbiosis with photoautotrophic protozoans are thus continually confronted with the problem that in order to live at depths where the water is penetrated by sufficient light, they must expose themselves and their symbionts to the potentially harmful UV component of the sun's radiation.

Whereas the bleaching of tropical corals (Madreporia) has been extensively studied, there have been relatively few studies of this phenomenor in the sea anemones (Actiniaria) with symbionts that live in the eulittoral and shallow sublittoral of temperate coastal regions. As semisessile organisms they, like the photoautotrophic symbiotic dinoflagellates that some of them contain in their gastrodermis, are especially exposed to sunlight, so that UV could be a very important environmental stressor for them. The purpose of this investigation was to evaluate the influence of UV at two different intensities on the dinoflagellate symbionts of Cereus pedunculatus (Pennant, 1977) in the short term, up to 9 days. The UV effects were analyzed exclusively at the ultrastructural level. The species was chosen for study because it is one of the few littoral anemones possessing endosymbiotic algae and having a local distribution that extends far into the temperate zones. 


\section{MATERIALS AND METHODS}

Cereus pedunculatus, an anemone with extremely variable coloration and an oral disk up to about $60 \mathrm{~mm}$ in diameter, inhabits the western Mediterranean, the Adriatic Sea, and the Atlantic coasts of Europe extending as far north as western Scotland and into the North Sea. With their relatively small pedal disk they cling to shells and stones; they are often buried up to the tentacles in soft sediments. Singly or in small groups, they can be found from the upper to the lower sublittoral (infralittoral and circalittoral), sometimes in places where it is so dark that they are almost entirely deprived of zooxanthellae and have a gray-white hyaline appearance (Schmidt, 1972).

The zooxanthellae are coccoid vegetative cells lacking flagella (diameter 9-10 $\mu \mathrm{m}$ ), with a structure typical of dinoflagellate symbionts (Dodge, 1968; Taylor, 1968; Cook, 1983). They occupy the cells of the gastrodermis.

On the basis of a generally morphological analysis, including ultrastructural investigations, it was believed for a long time that most dinoflagellate endosymbionts in cnidarians are of the species Symbiodinium microadriaticum (Freudenthal, 1962). Trench \& Blank (1987) used biochemical, physiological, morphological, and behavioural assays to demonstrate the presence of several closely related Symbiodinium species in various hosts. Indeed, Banaszak et al. (1993) warned that hosts of different taxd need not all harbor Symbiodinium-like dinoflagellates. The ultrastructure of the symbiotic cells of C. pedunculatus makes it likely that they do belong to this genus (Kevin et al., 1969), so for the time being we designate them merely as Symbiodinium sp.

\section{Origin and maintenance of sea anemones}

All the sea anemones investigated were clonal or inbreeding descendants of a single specimen, and between 4 and 6 months old. The parental specimen had been collected from a shallow rock pool near Cap Erquy (Brittany, France) in October, 1984. The individuril animals were kept in sand on Petri dishes $(5 \mathrm{~cm}$ diameter) filled half up with sand in an aquarium system with constant water circulation, consisting of five communicating $110 \mathrm{dm}^{3}$ glass vessels $(80 \times 35 \times 40 \mathrm{~cm})$ containing artificial seawater (WIMEX) at $18^{\circ} \pm 2{ }^{\circ} \mathrm{C}$. The dishes were illuminated in a light-dark cycle (LD 12:12,13 $\mathrm{W} \mathrm{m}^{-2}$ ) with Lumilux-Daylight tubes (36 W/11-860, Osram, Germany). Daily low tide (10:00 to 16:00) was simulated by pumps. The anemones were fed twice a day with Artemia nauplii.

\section{UV irradiation}

The LD 12:12 was continued during the experiments (visible-light intensity $13 \mathrm{~W}$ $\mathrm{m}^{2}$; Lumilux-Daylight tubes, 36 W/11-860, Osram, Germany). UVA-340 tubes (Q-Panel CO, USA) were used to produce quasisolar UV radiation during simulated low tide. The visible and UV radiation together had the spectral energy distribution shown in Fig. 1. During UV irradiation the animals were $0.5-1.0 \mathrm{~cm}$ below the water surface. The UV onset was abrupt, so that no gradual adaptation was possible. UV-B intensities in the experiments were up to two times higher than the approximate mean habitat-specific UV-B light intensities $\left(0.5 \mathrm{~W} \mathrm{~m}^{-2}\right)$ measured at a North Sea site of littoral Metri- 


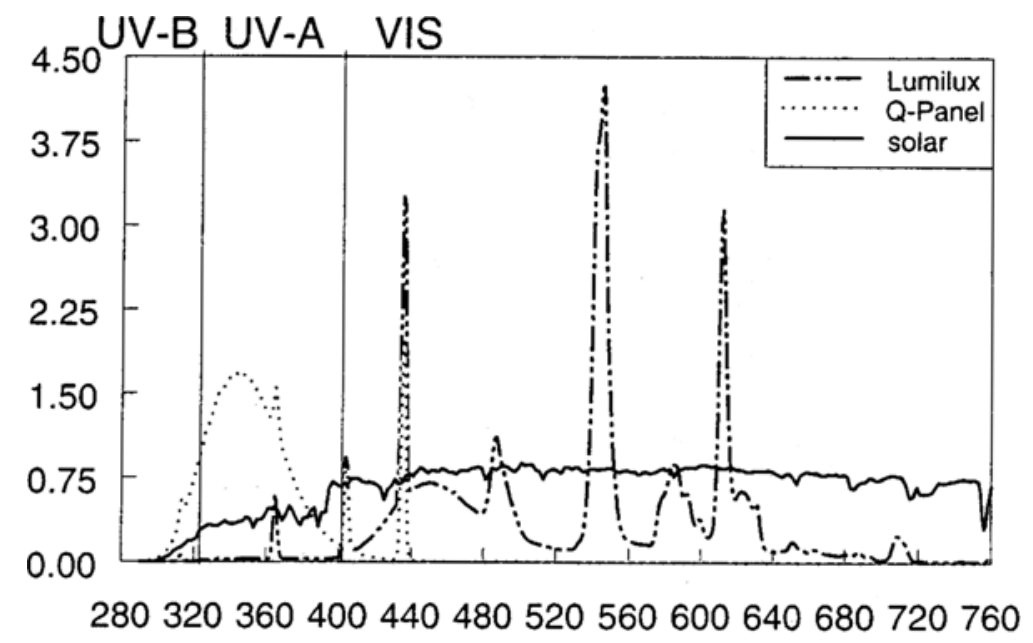

wavelength / $\mathrm{nm}$

Fig. 1. Spectral distribution of the radiation in simulated solar light, produced by a combination of tubes for the UV (Q-Panel) and the visual (Lumilux) ranges. The reference curve shows solar radiation on a typical summer day in Zingst (Baltic Sea) measured with a MAC.AM spectroradiometer (courtesy of Dr. R. Forster, University of Rostock)

dium senile anemones near Wilhemshaven on a typical sunny summer day. The Cereus were exposed to the experimentally added UV light for $6 \mathrm{~h}$ daily, from 10:00 to 16:00. The UV tubes were set $10 \mathrm{~cm}$ above the Petri dishes, giving UV-B intensities of up to $1 \mathrm{~W} \mathrm{~m}{ }^{2}$ and UV-A intensities up to $5.7 \mathrm{~W} \mathrm{~m}^{2}$. UV radiation was measured with a UVA/B-meter (No. 1533; Dr. Hönle, Planegg, Germany), which was calibrated with a spectroradiometer (MACAM PHOTOMETRICS, Livingstone, UK). After two, five, and nine days of irradiation, tentacle samples were taken for fixation. In the controls, the animals were exposed exclusively to visible light.

\section{Transmission electron microscopy (TEM)}

Tentacles from the anaesthetized $\left(8 \% \mathrm{MgCl}_{2}\right)$ sea anemones were cut near the base and fixed in $17 \%$ saccharose-buffered solution of $2.5 \%$ glutaraldehyde, picric acid, and formaldehyde at $4{ }^{\circ} \mathrm{C}$ for $2 \mathrm{~h}$. Tissues were washed with $0.075 \mathrm{M}$ phosphate buffer, $\mathrm{pH}$ 7.3 , and postfixed for $1 \mathrm{~h}$ in $0.15 \mathrm{M}$ phosphate-buffered $2 \%$ osmium tetroxide at $4{ }^{\circ} \mathrm{C}$. After dehydration in a graded series of ethanol, tentacles were transferred to propylene oxide and embedded in Epon 812. Serial sections were made with a diamond knife on a REICHERT Uitracut microtome, stained with uranyl acetate and lead acetate, and examined with a Zeiss EM 109 electron microscope. 


\section{Measurement of ultrastructural effects}

Data for the morphometric and statistical analyses were obtained from electron micrographs of tentacle cross sections. The measurements of symbiont density, diameter of the dinoflagellate cells, dimensions of chloroplasts and starch granules, and reproduction rate of the symbionts were fed into a PC by means of a digitizing pad and a Turbo Pascal program. Because the Kolmogorow-Smirnov test showed that the data were not normally distributed, the $U$ test of Mann \& Whitney was used to check for significance.

\section{RESULTS}

\section{Symbiont density}

In control animals, which had not been exposed to light with a UV component, the density of endosymbiotic dinoflagellates was $0.651 \pm 0.159$ cells per $100 \mu^{2}$ (Table 1 ) of gastrodermis tissue in the plane of section. In the anemones additionally irradiated with UV, the symbiont density was significantly lower (Figs 2, 3). A decrease in the number of zooxanthellae was even externally visible as bleaching of the tentacles, as well as clearly discernible in the sections of tentacles (Fig. 4). With a UV-B intensity of $1 \mathrm{~W} \mathrm{~m}$ : the symbiont density fell (Figs 2,3 ) exponentially over a period of 9 days $\left(\mathrm{r}^{2}=0.83\right)$. The reduction in number of cells was significant after 2 days and from the 2nd to the 5 th day $(\mathrm{P}<0.05$ ), but from Day 5 to Day 9 there was no significant decrease in number $(\mathrm{P}<0.05)$. With half that irradiation intensity $\left(0.5 \mathrm{~W} \mathrm{~m}^{2}\right)$, the symbiont density plotted as a function of UV dose was in the region of the exponential decline of Fig. 3 (Table 1 ).

Table 1. Density of symbionts of Cereus pedunculatus for three LV-B doses after exposure to quasisolar artificial irradiation with a UV-B intensity of $1 \mathrm{~W} \mathrm{~m}^{-2}$

\begin{tabular}{|c|c|c|c|c|}
\hline & \multicolumn{4}{|c|}{ Dose $/ \mathrm{kJ} \cdot \mathrm{ml}^{2}$} \\
\hline & 0 & 43.2 & 108 & 194.4 \\
\hline Density & 0.52 & 0.35 & 0.13 & 0.15 \\
\hline of & 0.46 & 0.23 & 0.27 & 0.18 \\
\hline symbionts & 0.85 & 0.41 & 0.21 & 0.18 \\
\hline per $100 \mu \mathrm{m}^{2}$ & 0.49 & 0.33 & 0.16 & 0.19 \\
\hline & 0.80 & 0.29 & 0.25 & 0.12 \\
\hline & 0.52 & & & 0.13 \\
\hline & 0.70 & & & 0.19 \\
\hline & 0.73 & & & 0.19 \\
\hline & 0.88 & & & \\
\hline & 0.56 & & & \\
\hline$N$ & 10 & 5 & 5 & 8 \\
\hline Mean & 0.651 & 0.322 & 0.204 & 0.166 \\
\hline Standard deviation & 0.159 & 0.067 & 0.059 & 0.029 \\
\hline
\end{tabular}




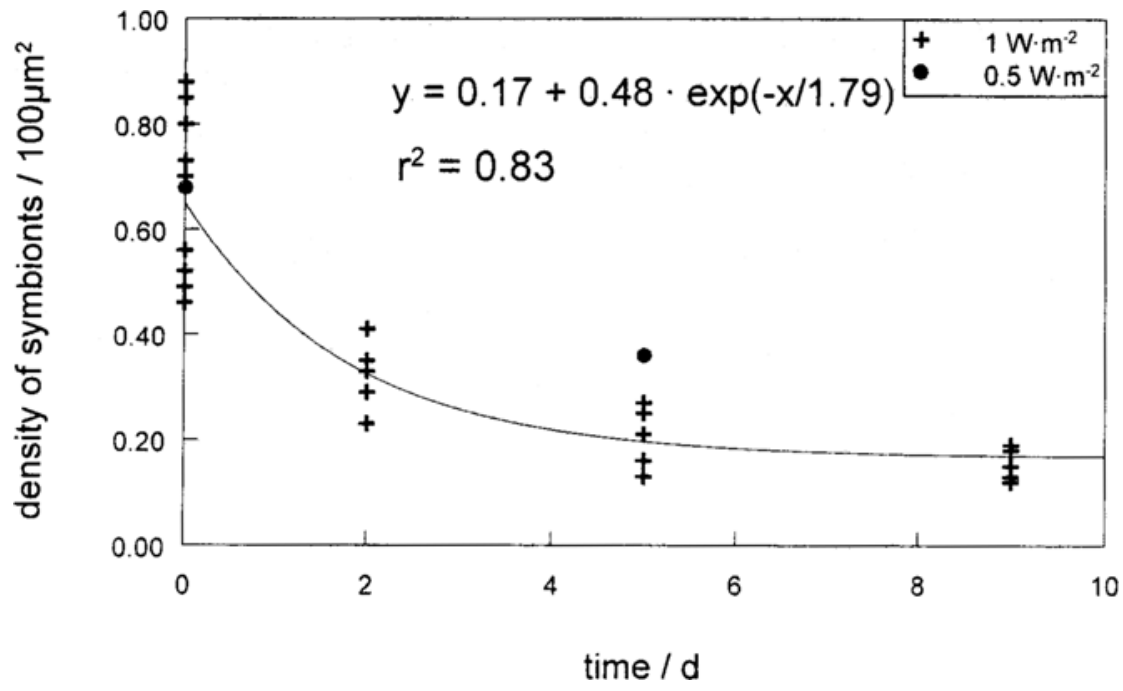

Fig. 2. Density of symbionts of Cereus pedunculatus as a tunction ol time of exposure to quasisolar cirtificial raciation at a UV-B intensity of $1 \mathrm{~W} \mathrm{~m}^{2}$. The function and determination coefficient of the best exponential fit are included. The dot shows the mean control value at half of the UV-B intensity

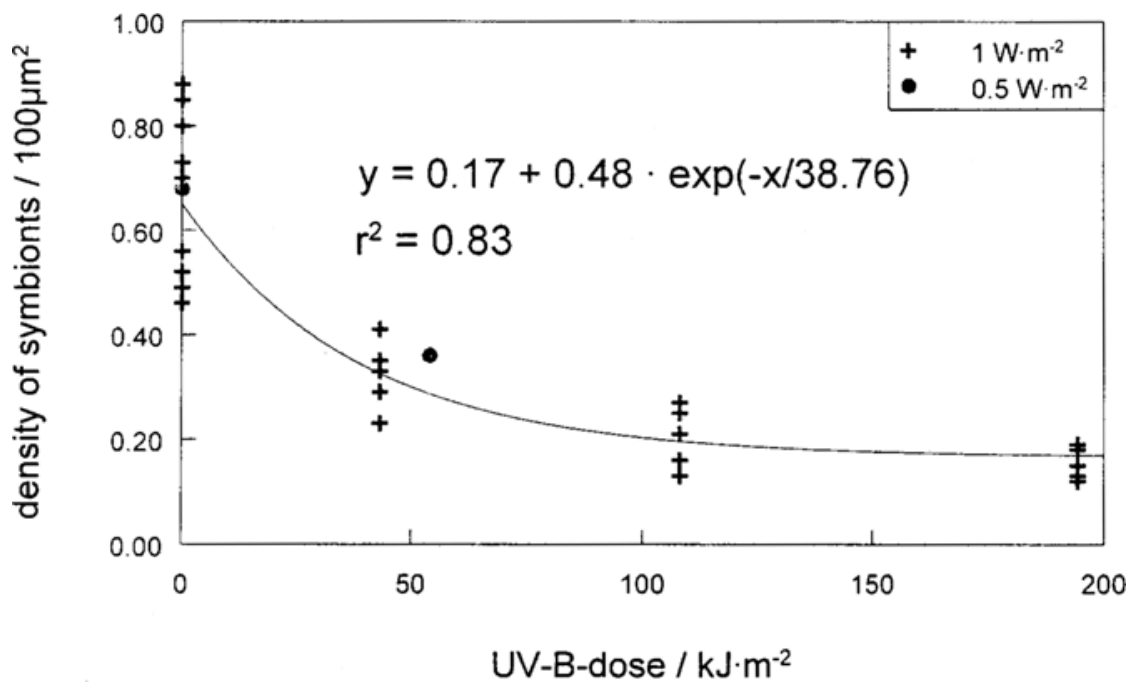

Fig. 3. Density of symbionts of Cereus pedunculatus as a function of UV-B dose during exposure to quasisolar artificial irradiation with a UV.B intensity of $1 \mathrm{~W} \mathrm{~m} \mathrm{~m}^{-2}$. The function and determination coefficient of the best exponential fit are included. The dot shows the mean control value at the dose corresponding to half of the UV-B intensity 


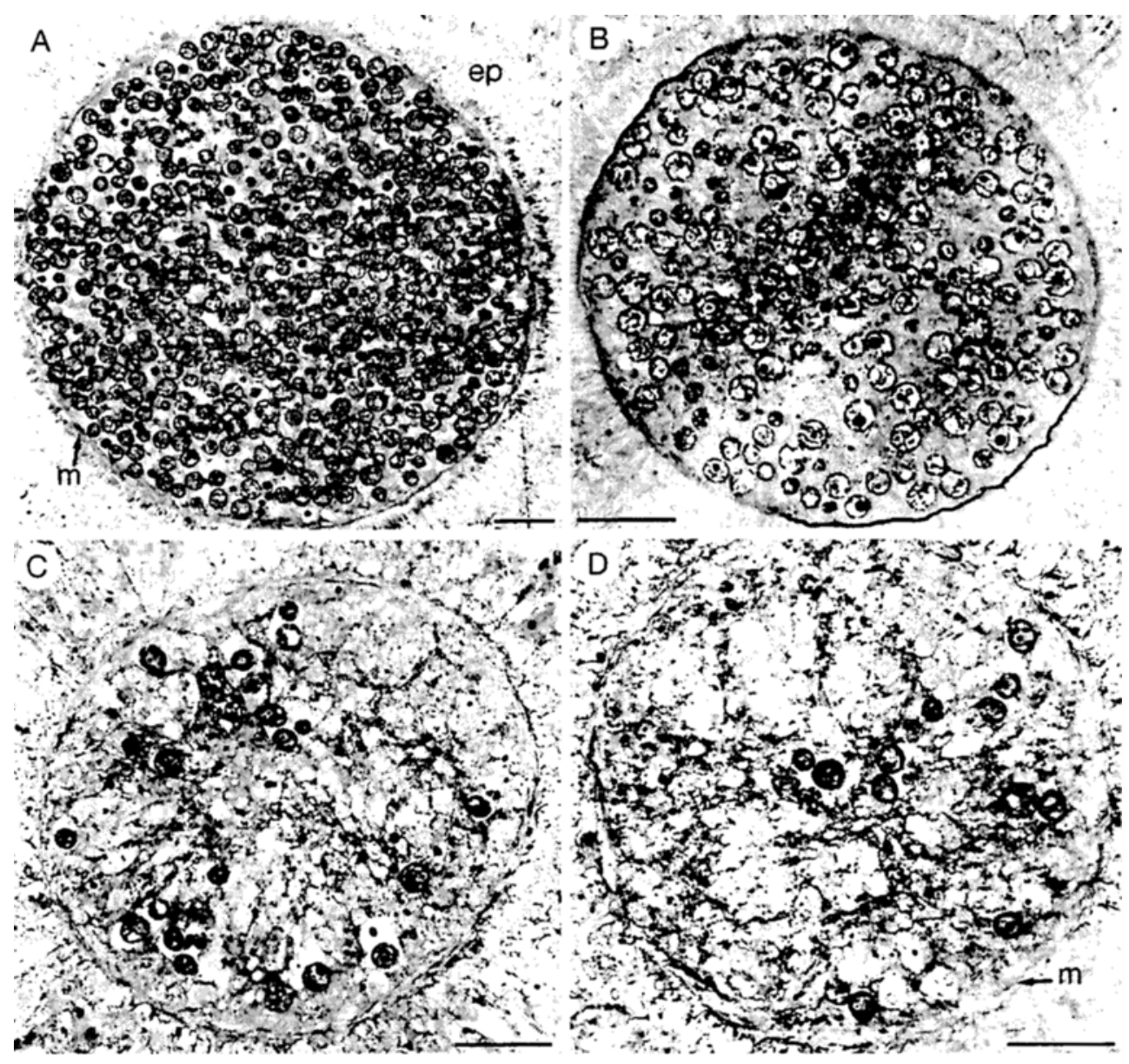

Fig. 4. Cereus pedunculatus. Cross sections of gastrodermis with zooxanthellae, distal area of tentacle. A. From an individual exposed to visible light exclusively. B. From an individual exposed additionally to $\mathrm{LV}$ light $\left(1.0 \mathrm{~W} \mathrm{~m}^{-2}\right)$ for $2 \mathrm{~d}, 6 \mathrm{~h}$ daily. C. From an individual exposed additionally to UV light $\left(1.0 \mathrm{~W} \mathrm{~m}^{-2}\right)$ for $5 \mathrm{~d}, 6 \mathrm{~h}$ daly. D. From an individual exposed additionally to UV light (1.0 $\mathrm{W} \mathrm{m}^{-2}$ ) for $9 \mathrm{~d}, 6 \mathrm{~h}$ daily. Bars: $25 \mu \mathrm{m}$. ep epidermis, $\mathrm{m}$ mesogioea

\section{Symbiont size}

The size of the zooxanthellae, here expressed as the average of the areas of the individual symbionts in a TEM cross-section, was $36.2 \pm 18.12 \mu \mathrm{m}^{2}$ in the non-UV-irradiated control animals. After UV irradiation, significant size increases were observed, to some extent correlated with intensity. With an irradiation intensity of $1 \mathrm{~W} \mathrm{~m}^{-2}$, the symbionts were $47 \%$ larger after only two days, but after five or nine days of irradiation their average sizes were only about $17 \%$ above the control value (Table 2 ). 
Table 2. Size of symbionts of Cereus pedunculalus after exposure to quasisolar artificial irradiation with a UV-B intensity of $1 \mathrm{~W} \mathrm{~m}^{2}$

\begin{tabular}{|c|c|c|c|}
\hline Time of irradiation & UV-B light intensity & $\begin{array}{l}\text { Size of symbionts } \\
\left(\mu \mathrm{m}^{2}\right)\end{array}$ & Difference \\
\hline Control & 1 & $36.2 \pm 18.12$ & \\
\hline 2 days & $1 \mathrm{~W} \mathrm{~m}^{-2}$ & $53.3 \pm 23.45$ & $+47 \%$ \\
\hline 5 days & $1 \mathrm{~W} \mathrm{~m}^{-2}$ & $42.6 \pm 18.12$ & $+17 \%$ \\
\hline 9 days & $1 \mathrm{~W} \mathrm{~m}^{2}$ & $42.6 \pm 19.18$ & $+17 \%$ \\
\hline
\end{tabular}

\section{Ultrahistopathology of irradiated zooxanthellae}

Chloroplast structure. After UV irradiation almost all the TEM sections showed distinct changes in the ultrastructure of the chloroplasts (Figs 5,6), regardless of the duration of exposure or radiation intensity

A characteristic feature was loosening of the thylakoids, which normally are regularly and tightly packed. More or less large interstices had formed between them, so that their compact, parallel arrangement was lost to a greater or lesser degree. At the ends of the disc-like thylakoids, in particular, the membranes had spread apart so far as to form bulbous structures resembling vesicles. In some cases large vesicles had constricted off, and it was probably by fusion of these that larger, isolated, empty-appearing vacuoles had formed. As a result of this internal expansion, the area of the chloroplasts as a whole was much larger in the cross sections, and hence so was the overall volume of the symbionts. The greatest increase in chloroplast area was measured (see

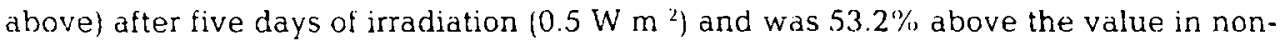
irradiated cells, i.e. the chloroplast comprised $62.0 \% \pm 6.6 \%$ in the irradiated cells. Many electron-lucent vacuoles, some very large, also appeared in the cytoplasm outside the chloroplasts; their origin is unknown.

Starch volume: In symbionts of irradiated sea anemones, the starchy coating around the pyrenoid became less extensive, and the proportional area (relative to the overall area of the symbiont) occupied by starch granules was reduced. The latter fell continuously from the original $12.9 \% \pm 3.6$ : to $6.4 \% \pm 3.1$ after 2 days of irradiation, $4.3 \% \pm 2.0$ after 5 days, and $2.9 \% \pm 1.1$ after 9 days.

Mitochondrial structure: Changes in the mitochondria are relatively hard to quantify, because differences in their appearance in micrographs can result from differences in preparation. Nevertheless, it was clear that in the zooxanthellae of many irradiated animals the electron density of the mitochondrial matrix was reduced. The percentage of these organelles that appeared distinctly brighter was $17.3 \% \pm 7.5$ after 2 days, $22.7 \% \pm 9.5$ after 5 days and $29.4 \% \pm 12.8$ after 9 days (Fig. 7 ). The size of the mitochondria, however, was unaffected.

\section{Reproduction rate of the zooxanthellae}

In sections through the gastrodermis, a certain number of symbionts are observed to be undergoing mitosis; therefore, the percentage of the total number of symbionts in a tentacle cross section that are in the process of division can be taken as a measure of 


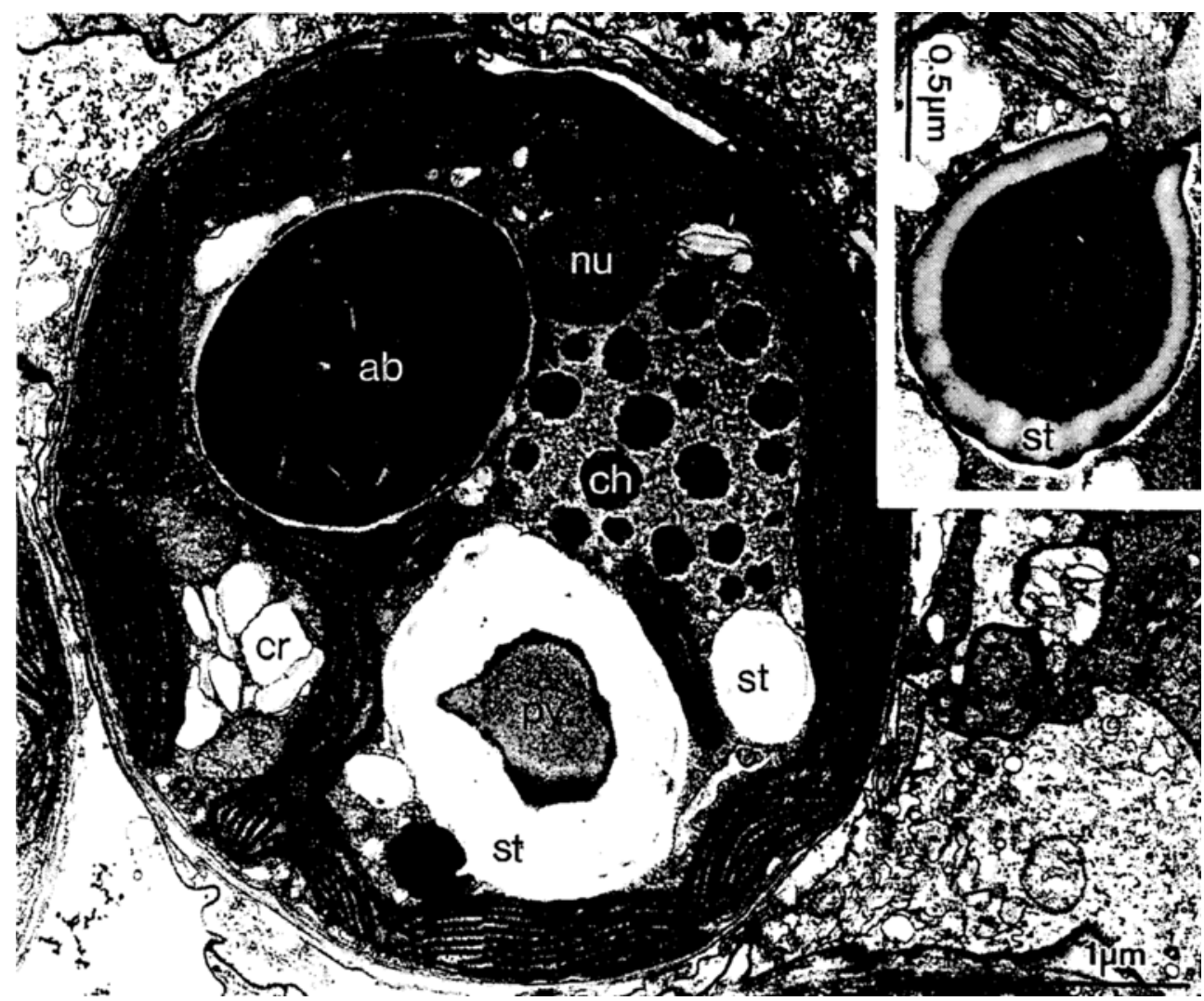

Fig. 5. Electron micrograph of Symbiodinium sp. zooxanthella from non-UV-irradiated Cereus pedunculatus, showing the microanatomy of a normal cell. The boundary between symbiont and host cell is a typical highly complex periplast, consisting of 4 membranes with an amorphous layer sandwiched between each of the adjacent membranes. The innermost membrane is the actual plasma membrane of the symbiont. The vase-shaped pyrenoid (py) is connected to the chloroplast by a stalk-like structure (see inset) and completely enclosed in a membrane that is evidently derived from the internal chloroplast membrane; thylakoids do not penetrate the matrix of this pyrenoid. It is encapsulated in a more or less voluminous starch coating (st) with no peripheral membrane. A similarly shaped structure is the accumulation body (ab); situated within a vacuole, It is thought to be a waste depository for products of metabolic decomposition and is a typical feature in the non-motile vegetative stages of the symbionts. The mitochondria (mi) possess tubulelike cristae (see also Fig. 7). The nucleus ( $n$ ) (diameter $3-3.5 \mu \mathrm{m}$ ) contains a rounded nucleolus (nu). As is characteristic of dinoflagellates, the short chromosomes (ch) are permanently condensed and hence are always easily visible. Starches (st) are also present in the form of round to ovoid granules of various sizes, crystalline structures (calcium oxalate?) (cr) have practically the same electron density as the starch granules but are distinguishable by their angular shape. There is a large single multilobed chloroplast (cp) situated in the periphery of the cell and continuously enveloped by three membranes. It contains numerous lamellae with a variable number of closely stacked thylakoids in parallel orientation. The chloroplast matrix is relatively electron-dense and contains granules of different sizes; in micrographs at low magnification the matrix appears almost homogeneous 

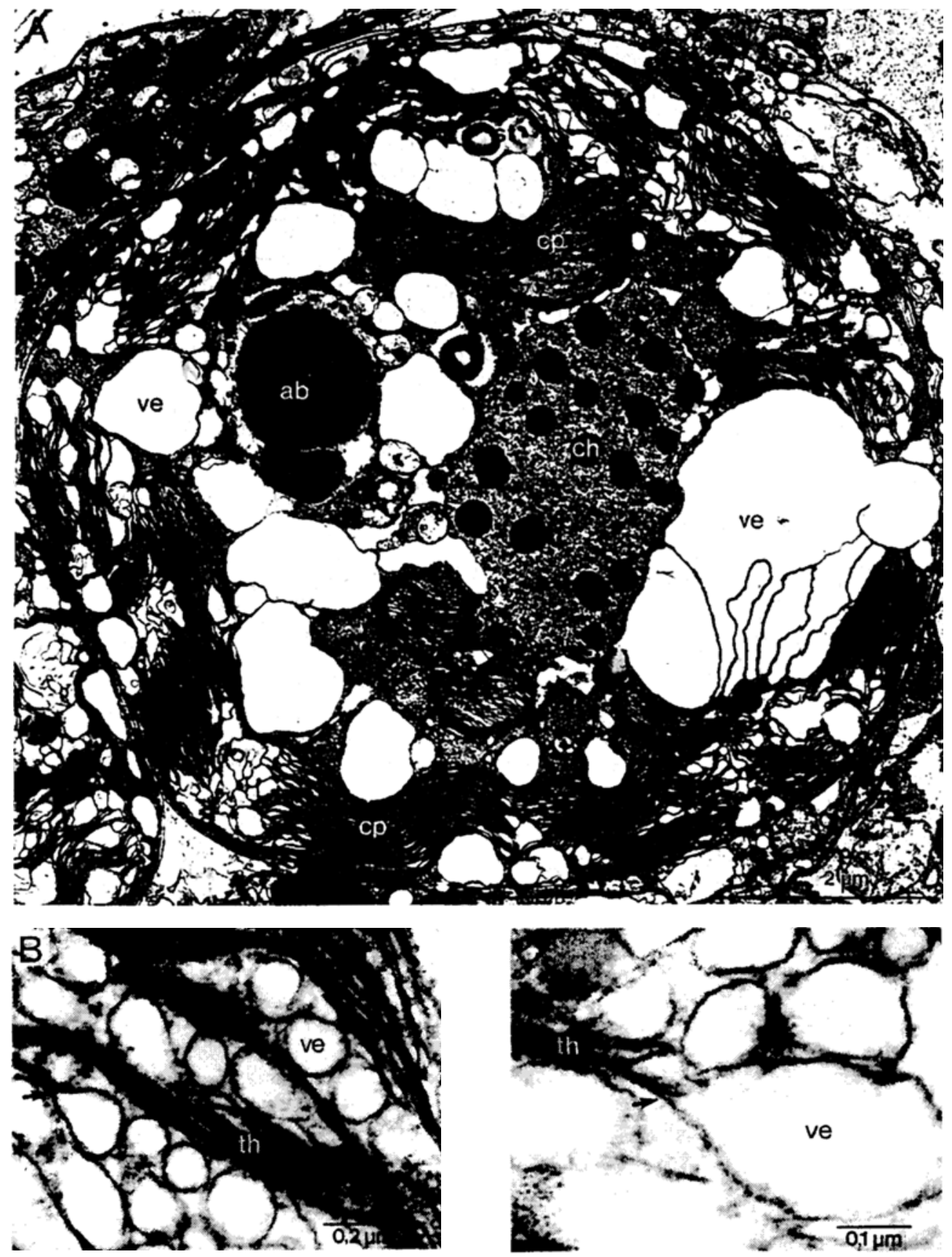

Fig. 6. Symbiodinium sp. after 9 d exposure to UV light (1.0 $\mathrm{W} \mathrm{m} \mathrm{m}^{2}, 6 \mathrm{~h}$ daily). A. Total cross section. B. Thylakoid membranes (th) spread apart forming large vesicles (ve) (arrows). ab accumula- 

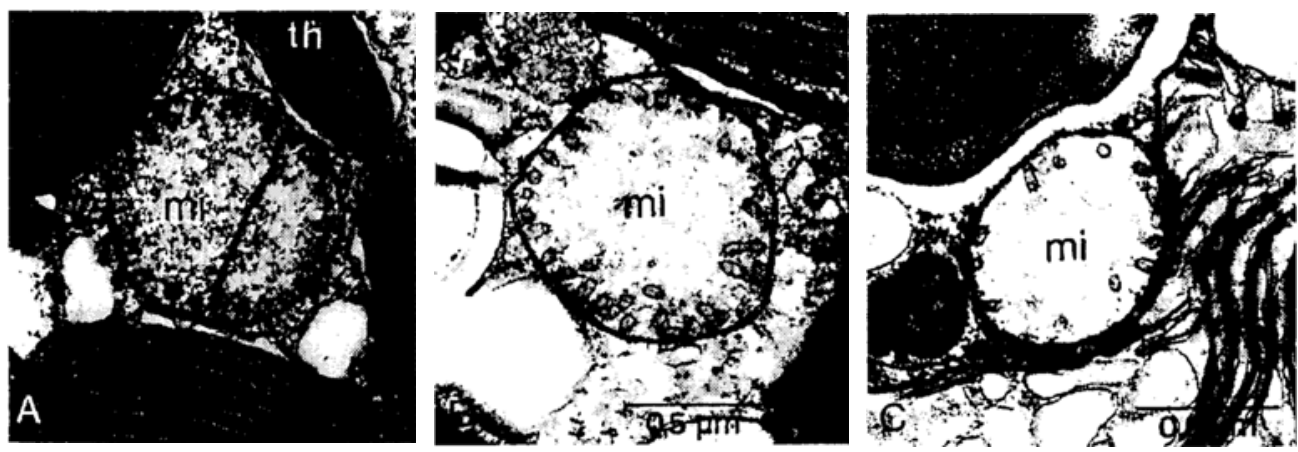

Fig. 7. Mitochondria (mi) of Symbiodinium sp. in Cereus pedunculatus. A. From an individud exposed to visible light exclusively. B. From an individual exposed additionally to UV light 11.0 $\mathrm{W} \mathrm{m}$ ) for $5 \mathrm{~d}, 6 \mathrm{~h}$ daily. (C. From an individual exposed to UV light $\left(1.0 \mathrm{~W} \mathrm{~m}^{2}\right)$ for $9 \mathrm{~d}$. 6 h daily

reproduction rate. In the non-UV-irradiated sea anemones, $6.6 \% \pm 3.2$ of the symbionts were in some stage of mitosis.

After 2 days of irradiation at $1 \mathrm{~W} \mathrm{~m} \mathrm{~m}^{2}$, the proportion of zooxanthellae in mitosis was merely $1.8 \%$ below the control value. At higher intensities, however, the reproduction rate fell distinctly, amounting to only $88.6 \%$ of the initial value after 9 days. In some tentacle sections, no mitotic stages at all could be found.

\section{DISCUSSION}

That artificial ultraviolet radiation is a major stress factor for tree-living dinoflagellate phytoplankton has been established by extensive investigation. Studies of Häder \& Brodhun (1991), Zündorf \& Häder (1991) and Häberlein \& Häder (1992) revealed that specific proteins were destroyed under the influence of UV radiation; in addition, the chromatophoric groups of the pigments were bleached. This results in reduced photosynthetic oxygen production (Zündorf \& Häder, 1991). Sites in photosystem II, in particular, will deteriorate (Renger et al., 1989; Khalilov et al., 1993). Dinoflagellates also may show considerable inhibition of motility, swimming velocity, and orientation mechanisms (Hläder \& Worrest, 1991; Schäfer et al., 1993). Whereas these planktonic dinoflagellates have been observed to sediment passively (Häder \& Liu, 1990), or to escape actively by downward swimming (Tirlapur et al., 1993; Schäfer et al., 1993) when exposed to excessive UV radiation, their endosymbiotic relatives that live in the tissues of sessile or hemisessile cnidarians are unable to actively avoid the stressor.

It is now evident that under UV irradiation in the laboratory the endosymbiotic dinoflagellates in the tentacles of Cereus decrease in number or vanish altogether. This finding has been quantified by counting the symbionts in crushed tentacle tips $(R$. Westholt, unpublished observation) as well as in the quantitative and qualitative ultrastructural analyses presented here. In these anthoz.oans, the symbiont reduction pro- 
duces externally visible "bleaching", a phenomenon known mainly in tropical corals and regarded there as cause for concern. The decrease in the number of zooxanthellae in the laboratory cannot be due to differences in nutrition, which have been shown to have a profound effect on zooxanthellae density (e.g. Janssen \& Möller, 1981; Muscatine et al., 1989); the test animals were fed living organisms in sufficient quantities, arcording to experience gained in many years of culturing and observing anthozoans. The possibility that differences in dinoflagellate densities in the tentacle regions might be associated with different origins of the animals, given the depth-dependent variation in density of zooxanthellae (Masuda et al., 1993), can also be ruled out; all the test animals were derived from a single individual taken from the intertidal region of the coast of Brittany, and at the beginning of the experiments each contained large numbers of symbionts. It follows that the bleaching of $C$. pedunculatus observed here is a direct effect of the UV irradiation, and this is corroborated in particular by the dosedependence of the decrease in number of symbionts.

In these experiments there were three conspicuous effects on the dinoflagellate cells: (1) UV radiation altered certain cytoplasmic structures; (2) the number of dividing cells decreased, implying a decrease in the rate of mitosis; (3) the total number of symbionts present was reduced, and in some cases they disappeared completely from the gastrodermis of the tentacles.

In fact, the structural damage is considerable even after brief irradiation at low intensities. The marked loosening of the thylakoid stacks and the formation of large vesicles are the main causes of the increase in cell volume. A correlated reduction in photosynthetic activity can be surmised and would also explain the clear decrease in total volume of the starch granules. Similarly, Buma et al. (1996) determined by ultrastructural examination of exposed cells of the marine diatom species, Cyclotella, that high UV-B radiation induced plasmolysis and disorientation of cell organelles. Among the effects of relatively low UV-B radiation treatments were volume enlargement and decreased division rates of the diatoms, supporting the notion that UV-B damages DNA and arrests the cell cycle in the S or G2 phase. Such an action could be responsible for the decreasing rate of mitosis in the zooxanthellae of Cereus. The extent to which the changed electron density of the mitochondria implies damage to the mitochondria is hard to evaluate; in any case, Masuda et al. (1993) suggest that reduction of respiration rates of isolated zooxanthellae may indicate that mitochondria are also damaged by UV radiation.

What cannot yet be determined is the fate of cells structurally altered in this way. If such severe damage generally condemned them to death, in which case they might be digested within the host cell or expelled into the gastric cavity, the reduction in numbers would be explained. Expulsion of the symbiont cells is considered to be a generalized stress reaction (Taylor, 1968; Høegh-Guldberg et al., 1987; Gates et al., 1992). But it cannot yet be ruled out that cells damaged to this degree, or at least some of them. have available repair mechanisms by which, after a certain period of adaptation or weakening of the UV stressor, they can regain their normal structure and become fully functional. However, when Hayes \& Bush (1990) histologically examined the repopulation of previously bleached gastrodermal areas in a scleractinian coral they found that recovery was not dependent upon proliferation of residual zooxanthellae in the bleached tissues but that cells in adjacent unbleached zones may migrate into the bleached zones. 
That coral bleaching can be induced by UV radiation and results from reduction in zooxanthellae clensities has increasingly come under discussion in recent years (Gleason \& Wellington, 1993; Shick et al., 1996). Previously bleaching, in particular the bleaching of corals, was usually ascribed to other causes: fluctuations in salinity (e.g., Høegh-Guldverg \& Smith, 1989), chiefly rising seawater temperatures (e.g., Brown \& Ogden, 1993; (.lynn, 1996), and recently bacterial infection (Kushmaro et al., 1996). Probably, bleaching is a multifactorial phenomenon, to which UV radiation may well be a major contribution (see, e.g., Drollet et al., 1995).

Corals, however, are thought to protect both their symbiotic dinoflagellates and their own tissues from the damaging effects of the UV stressor by producing UVabsorbing compounds, e.g., mycosporine-like amino acids (MAAs) (Shibata, 1969; Jokiel \& York, 1982, 1984; Drollet et al., 1993; Gleason, 1993; Vernet \& Whitehead, 1996; Shick et al., 1996). Why did such substances evidently not protect the symbionts in the present experiments? A likely explanation is that there was not enough time for them to be produced during the brief period of sudden exposure of Cereus to UV, with no preceding gradual adaptation. Dinoflagellates taken from Cereus individuals that had previously been exposed for years to regular UV stress were less damaged, quantitatively and qualitatively, when irradiated by UV with intensities and durations comparable to those in the present experiments (K. Hannack, unpublished observations). Furthermore, studies by Banaszak \& Trench (1995) suggest that Symbiodinium microadriaticum in isolation and in association with Cassiopeia xamachana synthesizes MAAs after exposure to UV.

Due to the specific irradiation regime in the present experiments, specification of the effects of UV-B or UV-A is not possible. It cannot be excluded that the effects seen might be related to UV-A or to blue light or to a combination with UV-B but not to UV-B alone (see Fitt \& Warner, 1995). Experiments that could distinguish any radiation specificity of this kind in Cereus pedunculatus and its zooxanthellae are still to be carried out.

Acknowledgements. Sincere thanks dre due to Dr. Rod Forster, University of Rostock, who assisted in calibration of our UV-meter. We thank Rainer Westholt for supplying us with sea anemones and for helping in carrying out experiments. We also thank Annd Stein, Monika C. Müller and Werner Mangench for introducing one of us (K. H.) to electron microscopy and Peter Kache for assistance in statistical techniques. Andred Noël kindly prepared the manuscript. This work was supported by research grant BEO 71/03FO120B “Wirkung von UV-Strahiung auf marine Organismen (UV-MAOR)", BMBF. The authors thank Dr. Irmisch (BEO, Warnemünde) who organized the project.

\section{LITERATURE CITED}

Achituv, Y. \& Dubinsky, Z., 1990. The adaptation of symbiotic associations between zooxanthellae and corals at different light levels. In: Microbiology in poecilotherms. Fd. by R. Lesel. Elsevier Science Publisher, Amsterdam, p. 43-46.

Banaszak, A. T. \& Trench, R. K.. 1995. Effects of ultraviolet (UV) radiation on marine microalgalinvertebrate symbiosis. The synthesis of mycosporine-like maino acids in response to exposure to UV in Anthopleura elegantissima and Cassiopeia xamachana. - J. exp. mar. Biol. Ecol. 194. $233-250$.

Banaszak, A. T., Iglesias-Prieto, R. \& Trench, R. K., 1993. Scrippsiella velellae sp. nov. (Peridiniales) and Gloeodinium viscum sp. nov. (Phytodiniales), dinoflagellate symbionts of two hydrozoans (Cnidaria) - J. Phycol. 29, 517-.528. 
Benson-Rodenbough, B. \& Ellington, W. R., 1982. Responses of the sea anemone Bunodosoma cavernata (Bosc.) (Anthozod. Actiniaria. Actiniidae) to osmotic stress. - Comp. Biochem. Physiol. 72, 731-735.

Brown, B. E. \& Suharsono, 1990. Damage and recovery of coral reefs afferted by El Niño-related seawater warming in the Thousand Islands, Indonesia. - Coral Reefs 8, 16.3-170.

Brown, B. E. \& Ogden, J. E., 1993. Coral bleaching. - Scient. Am. 268, 44-50.

Brown, B. E., Dunne, R. P., Scoffin, T. P. \& Letissier, M. D. A., 1994. Solar damage in intertidal corals. - Mar. Ecol. Prog. Ser. 112, 312.

Buma, A. G. J., Zemmelink, H. J., Sjollema, K. \& Gieskes, W. W. C., 1996. L;V-B radiation modifies protein and photosynthetic pigment content, volume and ultrastructure of marine diatoms. Mar. Ecol. Prog. Ser. 142, 47-54.

Calkins, J. (Ed.) 1982. The role of solar ultraviolet radiation in marine ecosystems. Plenum Press, New York, $724 \mathrm{pp}$.

Coles, S. L. \& Jokiel, P. L., 1977. Effects of temperature on photosynthesis and respiration in hermatypic corals. - Mar. Biol. 43, 209-216.

Cook, C. B., 1983. Netabolic interchange in algae-invertebrate symbiosis. - Int. Rev. Cytol. (Suppl) 14.177-210.

Cook, C. B., Logan, A., Ward, J., Luckhurst, B. \& Berg, C. J., 1990. Elevated temperatures and bleaching on a high latitude coral reef, the 1988 Bermuda event. - Coral Reefs $9,45-49$.

Dodge, j. D., i 968 . The fine structure of chloropiasts and pyrenoids in some marine cinoflagellates. - J. Cell Sci. 3, 41-48.

Douglas, A. E., MCAuley, P. J. \& Davies, P. S., 1993. Algal symbiosis in Cnidaria. - J. Zool. 2'31, $175-178$

Drollet, J. H., Gilazion, P. \& Martin, P. M. V., 1993. A study of mucus from a solitary coral Fungia fungites (Scleractinia, Fungirdde) in relation to photobiological UV-adaptation. - Mar. Biol 11.5, $263-266$.

Drohlet, J. H., Faucon, M. \& Martin, P. M V.. 1995. Elevated sed-water temperature and solar UV-B flux associdted with two successive coral mass bleaching events in Tahiti. - Mar. Freshwat. Res $46,1153-1157$.

Fisk. D. A \& Ione, T. J., 198.5. Taxonomic and bathymetric patterns of bleaching corals, Myrmidon Reef, Queensland. In: Proceedings of the 5th International Coral Reef Congress. Ed. by $C$. Gabriel, J. Toffart \& B. Salvat. 149-154.

Fitt, W. K \& Warner, M. E., 1995. Bleaching patterns of four species of Carribean reef corals. - Biol Bull mar. biol. Lab., Wonds Hole 189, 298-307.

Fleischmann, E. M., 1989. The measurement and penetration of ultraviolet radiation into tropical marine water. - Limnol. Oceanogr. 34, 1623-1629.

Gates, R. D., 1990. Seawater temperature and sublethal coral bleaching in Jamaica. - Coral Reefs 8, 193. 198.

Gates, R. D., Baghdasarian, G. \& Muscatine, C., 1992. Temperature stress causes host cell detachment in symbiotic cnidarians: Implications for coral bleaching. - Biol. Bull. mar. biol. Lab.. Woods Hole 182, 324-332.

Gieskes, W. W. C. \& Kraay, 1990. Transmission of ultraviolet light in the Weddell Sea. Report on the first measurement made in Antarctic. - Biomass Newsl. 12, 12-14.

Gleason, D. F., 1993. Differential effects of ultraviolet radiation on green and brown morphs of the Caribbean coral Porites asteroides. - I.imnol Oreanogr. 38, 1452-1463.

Gleason, D. F. \& Wellington, G. M., 1993. Ultraviolet radiation and coral bleaching. - Nature, Lond. 365, 836-8.38.

Gleason, D. F., Bhartia, P. K., Herman, J. R., McPeters, R., Newman. P., Stolarski, R. S., Flynn, L., Labow, G., Larko, D., Seftor, C., Wellemeyer, C., Komhyr, W. D., Miller, A. J. \& Planet, W., 1993. Record low global ozone in 1992. - Science, N.Y. 260, 523-526.

Glynn, P. W., 1991. Coral reef bleaching in the 1980s and possible connections with global warming. - Trends Ecol. Evol. 6, 175-179.

Glynn. P. W. 1993. Coral reef bleaching: Ecological perspectives, - Coral Reefs 12, 1-17.

Glynn, P. W., 1996. Cordl reef bleaching: facts, hypotheses and implications. - Global Change Biol 2. 495- 509 .

Grigg, R. W. \& Dollar, S. J., 1990. Effects of natural and anthropogenic disturbance on coral reefs In: Corai reefs. Ed. by Z. Dubinsky. Elsevier, New York, 439-452. 
Häberlein, A. \& Häder, D. P., 1992. UV efferts on photosynthetic oxygen production and chromoprotein composition in the freshwater flagellate Cryptomonas S2. - Acta protozool. 31, 85-92.

Häder, D. P., 1996. Effects of enhanced solar UV-B radiation on phytoplankton. - Scientia mar. 60 (Suppl. 1). 59-63.

Häder, D. P. \& Brodhun, B., 1991. Effects of ultraviolet radiation on the photoreceptor proteins and pigments in the paraflagellar body of the flagellate, Euglena gracilis. - J. Pl. Physiol. 132. 6i 1-646.

Häder, D. P. \& Liu, S. M., 1990. Effects of artificial and solar UV-B radiation on the gravitactic orientation of the dinoflagellate, Peridinium gaternense. - FEMS Microbiol. Ecol. 73. 331-338.

Häder, D. P. \& Worrest, R. C.. 1991. Effects of enhanced solar ultraviolet radiation on aquatic ecosystems. - Photochem. Photobiol. 50, 459-468.

Harland, A. D. \& Davies, P. S., 1994. Time-course of photoadaptation in the sea anemone Anemonia viridis. - Mar. Biol. 119,45-51.

Harland, A. D., Fixter, L. M., Davies, P. S., Spencer, D. \& Anderson, R. A., 1992. Effect of light on the total lipid content and storage lipids of the symbiotic sea anemone Anemonia viridis. - Mar. Biol. 112, 253-258.

Hayes, R. L. \& Bush, P. G., 1990. Microscopic observation of recovery in the reef-building scleractinian coral, Montastrea annularis after bleaching on a Cayman reef. - Coral Reefs 8, 203-209.

Hoegh-Guldberg. O.\& Smith, G. J., 1989. The effect of sudden changes in temperature, light, and salinity on population density and export of zooxanthellae from the reef coral Seriatopora pistillato and Stylophora hystrix. - J. exp. mar. Biol. Ecol. 129, 279-303.

Huegh-Guldberg, O., McClosky, L. R. \& Muscatine, L., 1987. Expulsion of zooxanthellae by symbiotic cnidarians trom the Red Sea. - Corai Reeis 5, 201-204.

Jadp. W. C., 1985. An epidemic zooxanthellac expulsion during 1983 in the lower Florida Keys coral reefs: Hyperthermic ecology. In: Proceedings of the 5 th International Coral Reef Congress. Ed. by C. Gabriel, J. Toffart \& B. Salvat. 143-148

Janssen, H. H. \& Möller, H., 1981. Effects of varıous feeding conditions on Anemonia sulcata. Zool. Anz. 206, 161-170

Jokiel, P. L. \& Coles, S. L., 1974. Effects of heated effluent on hermatypic corals at Kahe Point, Oahu. - Pacif Sci. 28, 1-18.

Jokiel, P. L. \& Coles, S. L., 1977. Effects of temperature on the mortality and growth of Hawaiian reef corals. - Mar. Biol. 43, 201-208.

Jokiel, P. L. \& Coles, S. L., 1990. Responses of Hawaitan and the Indo-Pacific reef corals elevated temperature. - Coral Reets 8, 155-162.

Jokiel, P. L. \& York, R. H., 1982. Importance of ultraviolet radiation in photoinhibition of microalyal growth. - Limizul. Oceanogr. 25, 192-199.

Jokiel, P. L. \& York, R. H., 1984 . Solar ultraviolet photobiology of the reef coral Pocillopora damicornis and symbiotic zooxanthellae. - Bull. mar. Sci. 32, 301-315

Kevin. M. J., Hall, W. T., McLaughlin, J. J. A. \& Zahl, P. A., 1969. Symbiodinium microadriaticum Freudenthal, a revised taxonomic description, ultrastructure. - J. Phycol. 5, 341-350.

Khalilov, R. I., Khomutov, G. V. \& Tikhonov, H. N., 1993. Effect of ultraviolet radiation on structural-functional characteristics of the thylakoid membrane. - Russ. Pl. Physiol. 40, 338-342.

Kinzie. R. A. 1993. Effects of ambient levels of solar ultraviolet radiation on zooxanthellae and photosynthesis of reef coral Montipora verrucosa. - Mar. Biol. 116, 319-327.

Kushmaro, A., Loya, Y., Fine, M. \& Rosenberg. E., 1996. Bacterial infection and coral bleaching. Nature, Lond. 380, 396.

Lasker, H. R., Peters, E. C. \& Coffroth, M. A.. 1984. Bleaching of reef coelenterates in the San Blas Islands, Panama. - Coral Reefs 3, 183-190.

Lesser, M. P. \& Shick, J. M.. 1989. Effects of irradiance and ultraviolet raciation on photoadaptation in the zooxanthellae of Aipiasia pallida: primary production, photoinhibition, and enzymatic defenses against oxygen toxicity. - Mar. Biol. 102, 243-256.

Lesser, M. P., Stochaij, W. J., Tapley, D. W. \& Shick, J. M., 1990. Bleaching in coral reef anthozoans: effects of irradiance, ultraviolet radiation, and temperature on the activities of protective enzymes against active oxygen. - Coral Reefs 8, 225-232.

Masuda, K., Goto, M., Marayuma, T. \& Miyachi, S., 1993. Adaptation of solitary corals and their zooxanthellae to low light and LV-radiation. - Mar. Biol. 117,68.5-691.

McLaughlin. J. J. A., Zahl, P. A. \& Nowak, A., 1964. In vitro analysis, nutritional requirements and 
population dynamics of some free-living phytoplanktons and symbiotic algae (Zooxanthellae) In: 10th Intern. Botan. Congr., Edinburgh, 518 pp.

Muscatine, L., 1973. Nutrition of corals. In: Biology of coral reefs. Ed. by R. Endean. Acad. Press, New York, 2, 77-115.

Muscatine, L., 1980. Productivity of zooxanthellae. In: Primary productivity in the sea. Ed. by P. G Falkowski. Plenum Press, New York, 381-402.

Muscatine, L., Falkowski, P., Dubinsky, Z., Cook, P. A. \& McCloskey, L. R., 1989. The effect of external nutrient resources on the population dynamics of zooxanthellae in a reef coral. - Proc. R. Soc. London (Ser. B) 236, 311-324.

Pierce, S. K. \& Minasian, L. C. Jr., 1974. Water balance of a euryhaline sea anemone, Diadumene leucolena. - Comp. Biochem. Physiol. 49. 159-167.

Renger, G., Völker, M., Eckert, H.-J., Fromme, R., Hohm-Veit, S. \& Gräber, P., 1989. On the mechanisms of photosystem II deterioration by UV-B irradiation. - Photochem. Photobiol. 49, 97-105.

Schäfer, J., Sebastian, C. \& Häder, D. P., 1993. Effects of solar radiation on motility, orientation, pigmentation and photosynthesis in a green dinoflagellate Gymnodinium. - Acta protozool. 3.3. $59-65$.

Schmidt, H., 1972. Prodromus zu einer Monographie der mediterranen Aktinien. - Zoologicá, Stuttgart, 121, 1-146.

Shibata, K. 1969. Pigments and a UV-absorbing substance in corals and bluegreen algae living in the Great Barrier Reef. - Plant Cell Phys. Tokyo 10, 325-335.

Shick, J. M., Lesser, M. P. \& Jokiel, P. L., 1996. Effects of ultraviolet radiation on corals and other coral reef organisms. - Global Change Biol. 2, 527-54.5.

Smith, R. C. \& Baker, K. S., 1979. Penetration of UV-B and biologically effective dose rate in natural water. - Photochem. Photobiol. 29, 311-323.

Smith, R. C. \& Baker, K. S., 1984. The analysis of ocean optical data. Proceedings of the SPIE. Ocean Optics 489, 119-126.

Smith, R. C. \& Tyler, J. E., 1976. Transmission of solar radiation into natural waters. In: Photochem Photobiol. Rev. $1,117-155$.

Steele, R. D., 1976. Light intensity as a factor in the regulation of the density of symbiotic zooxanthellae in Aiplasia lagetes (Coelenterata, Anthozod). - J. Zool. 179, 387-405

Suharsono \& Brown, B. E., 1992. Comparative measurements of mitotic index in zooxanthellae from a symbiontic cnidarian subject to temperature increase. - J. exp. mar. Biol. Ecol. 158. $179-188$

Taylor. D. L., 1968. In situ studies on the cytochemistry and ultrastructure of a symbiotic marine dinoflagellate. - J. mar. biol. Ass. U.K. 48, 349-366.

Taylor. D. L., 1973. The cellular interactions of algal-invertebrate symbiosis. - Adv. mar. Biol. 11, $1-55$.

Tevini, M. (Ed.), 1993. UV-B radiation and ozone depletion. Effects on humans, animals, plants, microorganisms, and materials. Lewis Publishers, Boca Raton, $248 \mathrm{pp}$.

Tirlapur, U., Scheuerlein, R. \& Häder, D.-P., 1993. Motility and orientiation of a dinoflagellate, Gymnodinium, impaired by solar and ultraviolet radiation. - FEMS Microbiol. Ecol. 102. $167-174$

Trench, R. K. \& Blank, R. J., 1987. Symbiodinium microadriaticum Freudenthal, S. goreaui, sp. nov., $S$. kawaguti, sp. nov., and $S$. pilosum, sp. nov.: gymnodinoid dinoflagellate symbionts of marine invertebrates. - J. Phycol. 23, 469-481.

Vernet, M. \& Whitehead, K. 1996. Release of ultraviolet-absorbing compounds by the red-tide dinoflagellate Lingulodinium polyedra. - Mar. Biol. 127, 35-44.

Williams, E., Goenagd, C. \& Vicente, V., 1987. Mass bleaching on the Atlantic coral reefs. Science. N.Y. 238, 877-878.

Zündorf, 1. \& Häder, D . P. 1991. Biochemical and spectroscopic analysis of UV effects in the marine flagellate Cryptomonas maculata. - Archs Microbiol. 156, 405-411. 